\title{
MACROECONOMIC CHARACTERISTICS OF FINANCIAL AND ECONOMIC SUSTAINABILITY OF TRADE ENTERPRISES IN UKRAINE
}

\author{
Oleksandr Gerega' ${ }^{1}$
}

\begin{abstract}
The relevance of the researching and ensuring financial and economic sustainability of trade is proved. The essential structural characteristics of financial and economic sustainability are generalized. The specifics of managing thefinancialandeconomicsustainability oftradebusinessareindicated.Themacroeconomiccharacteristics of financial and economic sustainability of trade in Ukraine as the volume of equity, balance currency, sales of goods of the trade enterprises, current assets, current liabilities and provision, own current assets of trade enterprises are analysed. The financial and economic sustainability of trade enterprises in Ukraine was assessed using the ratios of provision of current assets to own funds, provision of stocks with own funds, maneuverability of equity, mobility, permanent assets, financial stability and financial dependence. Purpose. The purpose of the research is to analyse the condition and development trends of macroeconomic characteristics of financial and economic sustainability of trade in Ukraine and justification proposals for public policy to stimulate its strengthening. Methodology. The following scientific methods were used during the research: analysis, synthesis and comparison - to research the prerequisites for ensuring the financial and economic sustainability of trade enterprises; statistical analysis to calculate the key macroeconomic characteristics of financial sustainability and liquidity of trade enterprises; groupings, logical analysis, strategic management - to form priorities and means of state policy to stimulate the strengthening of financial and economic sustainability of trade business. Results. The low level of financial sustainability and liquidity of the trade sector in Ukraine has been empirically proven. It is established that a critical decrease in the financial and economic sustainability of the trade business occurred in 2014-2015. In 2012, the level of financial sustainability and liquidity of trade enterprises was the highest. Since 2016, the gradual restoration of financial and economic sustainability of trade business in Ukraine has begun. However, its level is still insufficient, which requires justification and implementation of effective measures of state regulation in this area. It is proved that strengthening the financial and economic sustainability of trade enterprises in Ukraine requires the formation and implementation of a common (state and business entities) policy aimed at strengthening the financial and economic sustainability of trade enterprises in Ukraine. The policy should be implemented in the following areas: alternative forms of the financial result formation, improvement of financial and economic attractiveness of enterprises, distribution of financial and economic risks with the manufacturing sector, realization of financial potential of domestic market by enterprises. Practical implications. The means of the state policy of stimulation and strengthening of financial and economic sustainability of the trade enterprises in Ukraine are defined. Value/originality. The methodical approach to the formation of tools and means of policy to strengthen the financial and economic sustainability of the country's trade business has been further developed.
\end{abstract}

Key words: financial and economic condition, sustainability, trade enterprises, macroeconomic parameters, policy of financial and economic development.

JEL Classification: G32, L81, M21

\section{Introduction}

During the period of Ukraine's independence, most macroeconomic indicators of financial and economic development of retail enterprises are improving. In some periods, the growth rate slowed down, the structural characteristics of the dynamics changed and opposite trends were observed. Accordingly, it is necessary to identify

\footnotetext{
Corresponding author:

${ }^{1}$ Lviv University of Trade and Economics, Ukraine.

E-mail: gerega2000lute@ukr.net

ORCID: https://orcid.org/0000-0001-5329-6915
} 
and implement measures aimed at strengthening the positive and levelling of negative impacts on the activities of individual economic agents and rational socio-economic development of trade in general. This involves the analysis of the hypothetical state of the business environment due to the implementation of measures of the public policy, implementation of previously adopted strategic economic, scientific and technical decisions, general trends and processes related to the formation of financial and economic potential of trade enterprises in Ukraine for proper adaptation to modern world transformations.

Awareness of the shortcomings in relation to the financial and economic conditions of commercial activity of the enterprises allows us to eliminate the most significant objective obstacles, as well as to stimulate the implementation of favorable development factors and improve its system and structural characteristics. Therefore, it is important when researching the conditions and factors of development the trade enterprises in Ukraine to take into account not only the areas of its influence (positive or negative), but also its full value in relation to all functions of the managing process of the potential the financial and economic sustainability.

It is also necessary to take into account the role of state regulatory bodies in ensuring the financial and economic stability of commercial enterprises, in particular in the context of the results of the relevant assessment. Any conclusion of analytical calculations will directly determine the quality of government regulation and the areas in which it will be necessary to ensure its effectiveness and progress in forecast periods. At the same time, government regulation should primarily provide for the use of tools and instruments that have a stimulating effect on the financial and economic stability of commercial enterprises.

Along with the formation of the system of state regulation at the enterprise level, there should also be institutional and structural changes related to the optimization of financial and economic potential, improvement of internal organizational work, expansion of investment and innovation partnerships and more.

\section{Brief literature review}

The analysis of recent research and publications shows that the proper financial and economic sustainability, efficiency, and availability of prerequisites for the development of trade enterprises depend primarily on the favorable resource functional and market factors (Vasyltsiv et al., 2020; Kutsyk et al., 2018; Kachmaryk et al., 2012).

The scientific approaches combine ideas about importance of resource functional factors. It has been taken into account when determining the availability, cost of involvement, levels of maintenance and use, as well as the characteristics of the current supply of trade enterprises in quality cash, inventories, equity, staff, retail and warehouse space, information, intangible assets (Staverska, 2019; Savchenko et al., 2018; Kutsyk et al., 2016; Gerega, 2016; Koknayeva, 2012).

The proponents of the market approach characterize the availability for business entities of target market niches, property and rights of activity, as well as the volume and level of transaction costs in obtaining it (Delas et al., 2019; Vozniuk, 2012).

Relevant aspects of the functioning of trade enterprises are the subject of research by a number of scientists who both combine and share the preconditions and consequences of providing resources, reaching market agreements, etc. (Koptieva, 2020; Vasyltsiv et al., 2019; Kashchena, 2018; Lupak et al., 2017). However, the peculiarities of the modern period of economic development, trade and domestic market, changes in approaches and means of financial and resource support of development determine the justification of effective macroeconomic preconditions that form the financial and economic sustainability of trade enterprises in Ukraine.

\section{Macroeconomic preconditions for ensuring the financial and economic stability of trade enterprises of Ukraine}

It is known that an effective and rational state policy should be based on a reliable and complete information base that substantiates and realizes informed and effective management decisions (Kutsyk et al., 2020). In turn, the necessary information concerns both the quantitative characteristics of the current state and development trends in the analysed area, and the parameters of the institutional environment of its subjects, the development of its infrastructure, external and internal factors that determine it. All this confirms the importance of choosing trends that directly determine the level of financial and economic sustainability of trade enterprises. 
The financial and economic sustainability of entities largely depends on the amount and level of equity in the structure of its balance sheet. Therefore, it is negative that in 2010-2019 the amount of equity of trade enterprises in Ukraine decreased from 8.5 billion EUR to 6.5 billion EUR or decreased of $23.5 \%$ (Figure 1). At the same time, the balance currency of enterprises, on the contrary, increased by 4.9 billion EUR (or increase of $2.7 \%)$. Thus, the level of equity in the total balance currency of trade enterprises decreased - from $10.4 \%$ in 2010 to $7.5 \%$ in 2019 . The gap between the amount of equity of trade enterprises and the volume of its balance currency has also increased. If the corresponding figure was 72.9 billion EUR as of 2010, in 2019 it is 86.2 billion EUR.

The decrease in the amount of equity in the structure of the balance sheet of trade enterprises is evidence of the deterioration of its financial condition, in particular the ability to form its own non-current assets at its own funds. The operating of own non-current assets is more mobile, flexible and significantly cheaper to maintain.

It can be seen that in general, by 2013, the situation with the financial stability of domestic trade enterprises was improving: the amount of equity grew, as well as the balance currency of enterprises. For example, the highest values of its indicators were in 2012, when in the country in general and in trade in particular there was a revival of business activity largely against the background of the UEFA European Championship in Ukraine and Poland in 2012. It is about 108.4 billion EUR in balance currency and 10.4 billion EUR in equity.

It was a crisis in 2014, in particular the factors of the political crisis and external military aggression in eastern Ukraine. Thus, in 2014, the balance currency of trade enterprises decreased by $31.1 \%$. In absolute terms, the figure was 33.6 billion EUR. It is obvious that such reduction has led to a significant deterioration in the financial and economic sustainability (increasing losses) of the trading business due to its decapitalization. As a result, negative values of the amount of equity were obtained for enterprises in the industry.

It was possible to restore the positive value of the amount equity of trade enterprises only in 2017, when the figure was only 0.9 billion EUR. The coefficient of financial stability was 0.014 , which was perhaps the worst value for the entire period of independence.

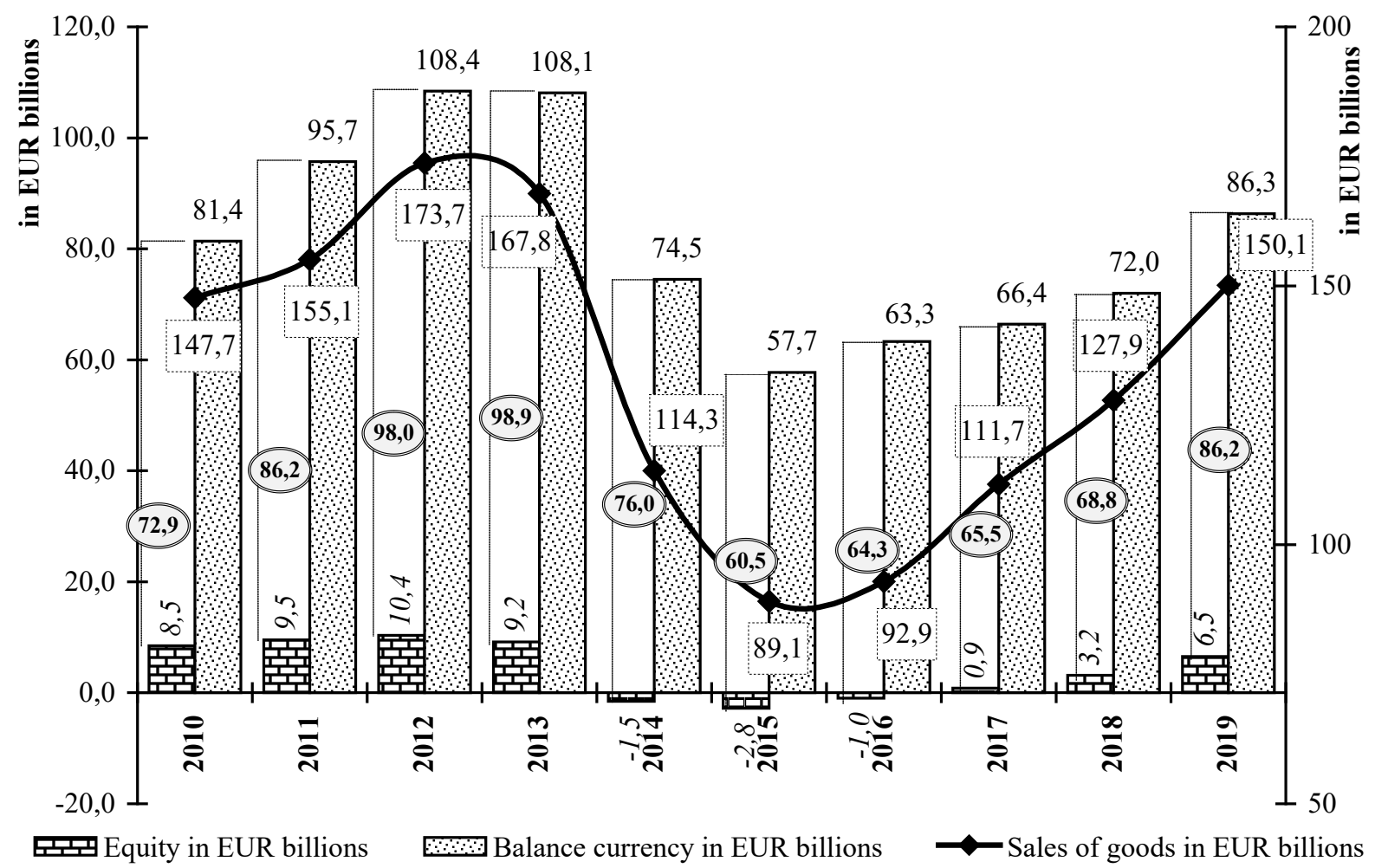

Figure 1. Equity, Balance Currency and Sales of Goods the Trade Enterprises of Ukraine in 2010-2019

Source: State Statistics Service of Ukraine 
On the positive side, there is a tendency to gradually improve the financial and economic condition of domestic trade from 2016 to 2019. It was achieved through a steady increase in sales of goods. For example, if in 2015, the trade turnover amounted to 89.1 billion EUR; in 2019, it increased to 150.1 billion EUR. The average annual growth rate of trade turnover of enterprises in 2015-2019 was about $17 \%$, which is quite high.

An important characteristic of the financial and economic sustainability of enterprises is its liquidity and solvency. As we can see from the information presented in Figure 2, during 2010-2019, in Ukraine trade enterprises were characterized by relatively acceptable liquidity, as the amount of current assets of enterprises exceeded the volume of its current liabilities.

The only exceptions were the crisis of 2014-2015, when current liabilities exceeded the current assets of trade enterprises in Ukraine. This was confirmed by the negative values of own current assets of trade entities ("minus" 1.7 billion EUR and "minus" 1.1 billionEUR in 2014 and 2015). The improvement of the situation and the growth of the analyzed indicator in 2016-2019 were positive phenomena, but so far, their level has not been restored for 2012, when the figure was 7.4 billion EUR.

\section{The results of assessing the financial and economic stability of trade enterprises of Ukraine}

The level of liquidity of the trade business in 2010-2019 remained insufficient in Ukraine. Thus, the total liquidity ratio in 2019 was only 1.04 , which is a low value, as in trade the relevant regulatory indicator should be 1.5-2.0. The total liquidity ratio for 2019 was even lower than for 2010 (1.05). The highest value of the indicator was typical for $2012-1.09$.

The general trends in terms of financial stability and liquidity of trade enterprises have affected the key parameters of financial and economic sustainability (Table 1). The most of the main indicators are unsatisfactory. These are, in particular, the ratios: provision of current assets with own funds, provision of stocks with own funds, permanent assets, financial stability and financial dependence.

Moreover, according to almost all these characteristics of the financial and economic

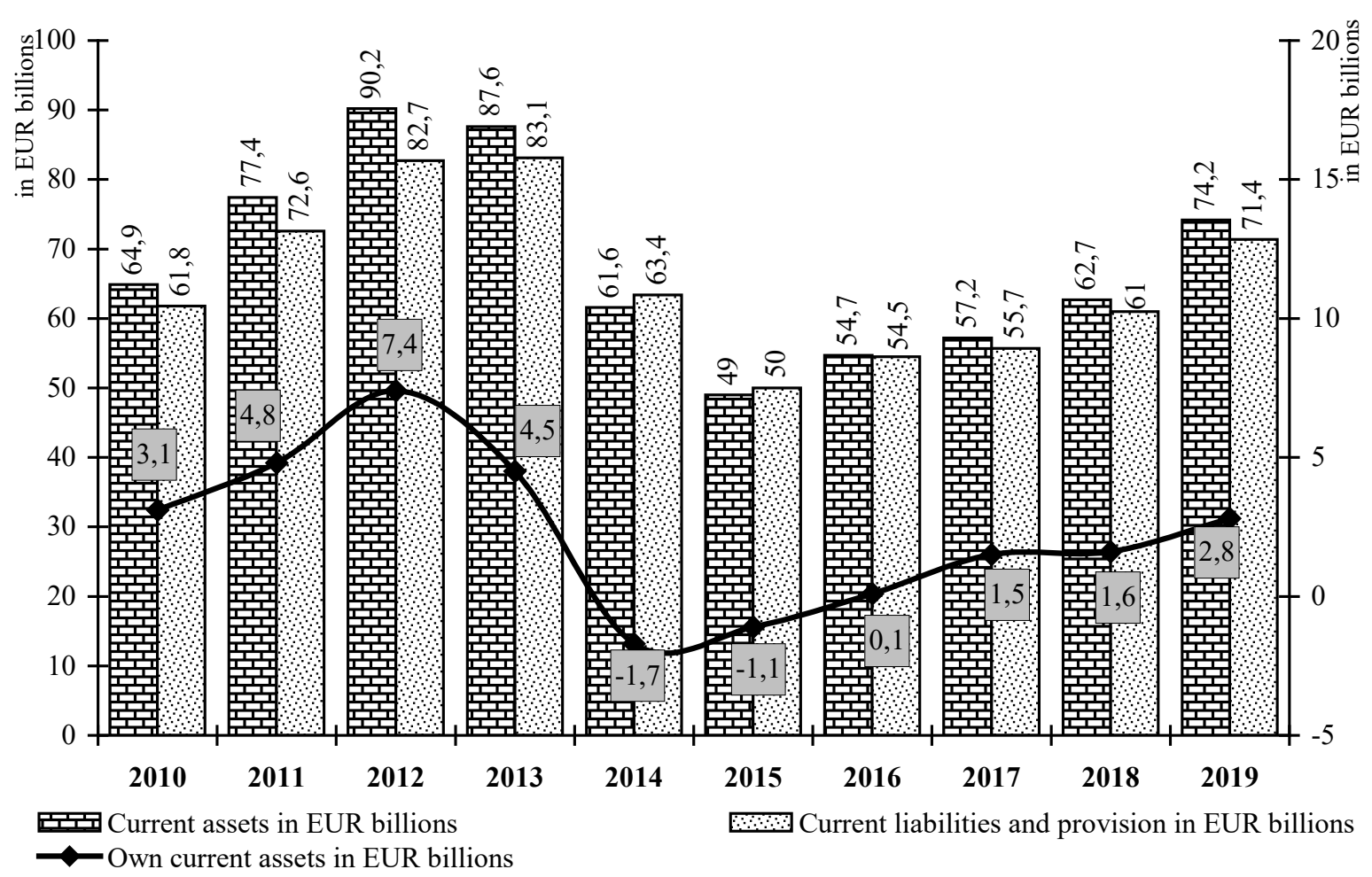

Figure 2. Current Assets, Current Liabilities and Provision,

Own Current Assets the Trade Enterprises of Ukraine in 2010-2019

Source: State Statistics Service of Ukraine 
Table 1

Indicators for Assessing the Financial and Economic Stability of the Trade Enterprises of Ukraine in 2010-2019

\begin{tabular}{|c|c|c|c|c|c|c|c|}
\hline \multirow{4}{*}{ Years } & \multicolumn{7}{|c|}{ Indicators } \\
\hline & $\begin{array}{c}\text { Ratios of } \\
\text { provision of } \\
\text { current assets } \\
\text { with own funds }\end{array}$ & $\begin{array}{l}\text { Ratios of } \\
\text { provision of } \\
\text { stocks with } \\
\text { own funds }\end{array}$ & $\begin{array}{c}\text { Ratios of } \\
\text { maneuverability } \\
\text { of equity }\end{array}$ & $\begin{array}{l}\text { Ratios of } \\
\text { mobility }\end{array}$ & $\begin{array}{c}\text { Ratios of } \\
\text { permanent } \\
\text { assets }\end{array}$ & $\begin{array}{l}\text { Ratios of } \\
\text { financial } \\
\text { stability }\end{array}$ & $\begin{array}{l}\text { Ratios of } \\
\text { financial } \\
\text { dependence }\end{array}$ \\
\hline & \multicolumn{7}{|c|}{ Recommended values } \\
\hline & $>0.1$ & $0.5-0.8$ & $0.3-0.5$ & $>0.5$ & reduction & $>0.8$ & $<0.5$ \\
\hline 2010 & 0.048 & 0.250 & 0.367 & 4.114 & 1.863 & 0.117 & 0.891 \\
\hline 2011 & 0.062 & 0.309 & 0.503 & 4.457 & 1.822 & 0.111 & 0.895 \\
\hline 2012 & 0.082 & 0.410 & 0.716 & 4.959 & 1.753 & 0.106 & 0.904 \\
\hline 2013 & 0.051 & 0.250 & 0.489 & 4.277 & 2.230 & 0.093 & 0.915 \\
\hline 2014 & -0.028 & -0.133 & 1.137 & 4.790 & -8.423 & -0.020 & 1.020 \\
\hline 2015 & -0.022 & -0.092 & 0.382 & 5.625 & -3.133 & -0.046 & 1.048 \\
\hline 2016 & 0.002 & 0.010 & -0.124 & 6.358 & -8.951 & -0.015 & 1.015 \\
\hline 2017 & 0.026 & 0.102 & 1.676 & 6.197 & 10.555 & 0.013 & 0.987 \\
\hline 2018 & 0.026 & 0.100 & 0.507 & 6.729 & 2.937 & 0.046 & 0.956 \\
\hline 2019 & 0.038 & 0.149 & 0.430 & 6.184 & 1.843 & 0.082 & 0.924 \\
\hline
\end{tabular}

Source: State Statistics Service of Ukraine

sustainability of the domestic trade business, the situation in 2010-2019 only worsened. Only indicators of maneuverability and mobility of enterprise capital were within more or less satisfactory limits.

The period of 2014-2015 was a crisis. Since 2016, the financial and economic sustainability of trade enterprises in Ukraine has been gradually improving, but as of 2019, its acceptable level has not been reached yet.

\section{Directions and tools of the policy of strengthening the financial and economic stability of trade enterprises in Ukraine}

Thus, the state of financial and economic sustainability of trade enterprises in Ukraine is insufficient, which leads to a slowdown in business activity in the industry, limiting opportunities, internal and external investment in enterprise development projects, deteriorating financial and economic efficiency and security. This situation needs to be corrected by implementing a policy aimed at strengthening the financial and economic sustainability of the industry (Figure 3 ).

\section{Conclusions}

The state of financial and economic sustainability of trade enterprises in Ukraine has significantly deteriorated starting from 2014-2015. During
2016-2019 it was characterized by a gradual improvement of financial and economic sustainability of trade enterprises. However, so far it has not been possible to ensure an acceptable level of financial and economic sustainability. In particular, evidence of this is below the acceptable values of such macroeconomic characteristics as financial stability and liquidity ratios: provision of current assets to own funds, provision of stocks with own funds, maneuverability of equity, mobility, permanent assets, financial stability and financial dependence.

Correction of this situation requires the formation and implementation of a common (state and business entities) policy aimed at strengthening the financial and economic stability of trade enterprises in Ukraine. It is appropriate that the policy is implemented in such areas and appropriate tools as (1) alternative forms of financial result formation (acceleration of trade turnover and reduction of turnover costs, increase of financial and economic efficiency of trade enterprises, diversification of trade activity), (2) improving the financial and economic attractiveness of enterprises (improving the impact of trade on spatial development, leveling regional and subregional disparities, increasing investment and innovation security of trade enterprises and its modernization, strengthening intersectoral cooperation and trade integration, creating food security conditions, creating conditions for development of trade 


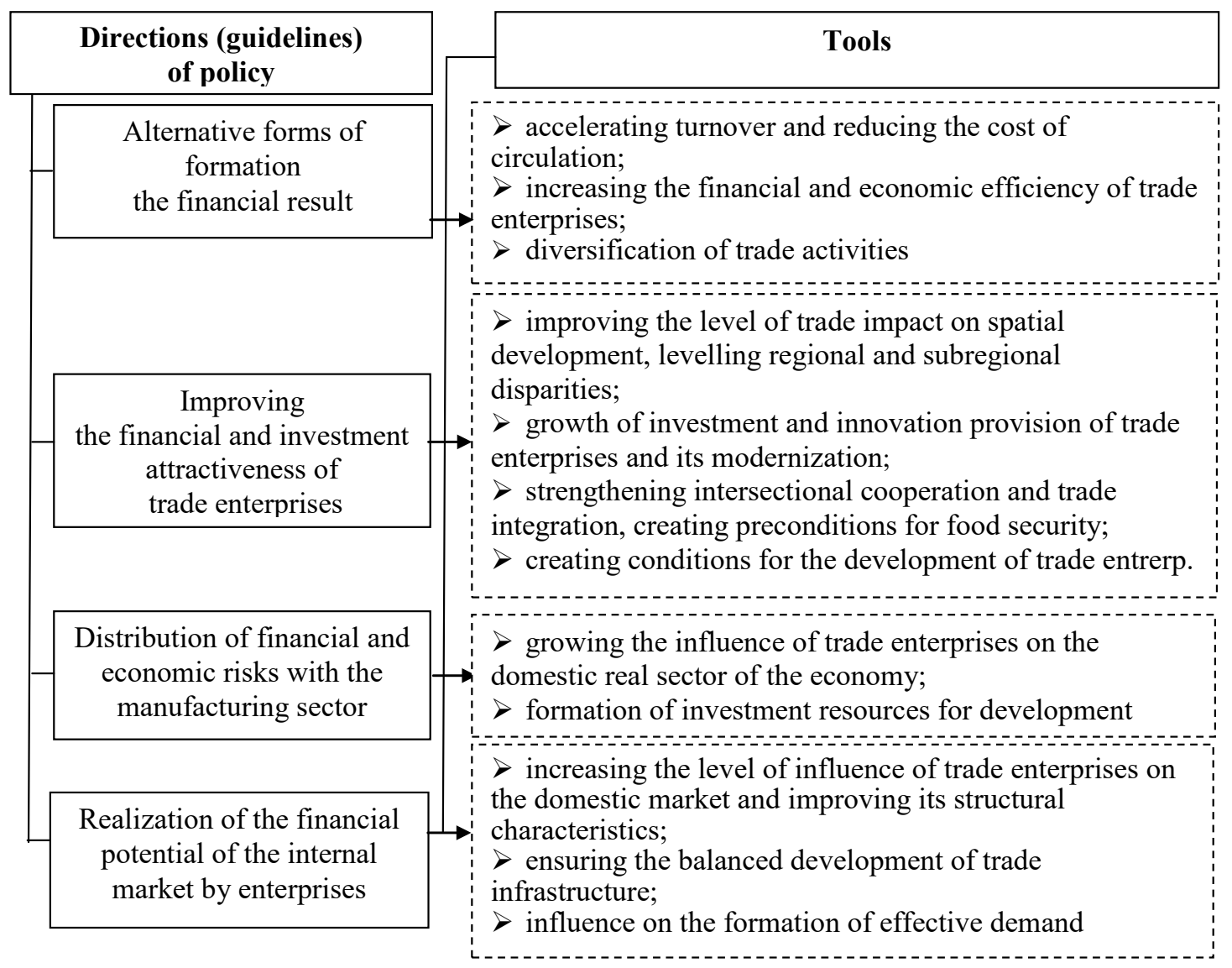

Figure 3. The Directions and Tools of the Policy of Strengthening the Financial and Economic Sustainability of Trade Enterprises in Ukraine

entrepreneurship), (3) distribution of financial and economic risks with the manufacturing sector (increasing the impact of trade enterprises on the domestic real sector of the economy, the formation of investment resources for development), (4) realization of the financial potential of the domestic market structural characteristics, ensuring the balanced development of trade infrastructure, the impact on the formation of effective demand). At the same time, this is not the final list of directions and instruments of the policy of strengthening the financial and economic stability of trade enterprises in Ukraine, because as globalization trends intensify, each of them will need to change or lose relevance. Thus, the following studies should focus on improving the policy of strengthening the financial and economic stability of Ukrainian trade enterprises.

\section{References:}

Delas, V., Nosova E., \& Yafinovych, O. (2019). Financial Security of Enterprises. Procedia Economics and Finance, vol. 27, pp. 248-266.

Gerega, O. V. (2016). Potentsial u systemi upravlinnia finansovo-ekonomichnoiu stiikistiu torhovelnoho pidpryiemstva [Potential in the management system of financial and economic stability of a commercial enterprise]. Entrepreneurship and trade, vol. 20(1), pp. 101-105.

Kachmaryk, Ya. D., Kutsyk, P. O., \& Lupak, R.L. (2012). Investytsiina pryvablyvist resursnoho potentsialu torhovoho pidpryiemstva [Investment attractiveness of the resource potential of a commercial enterprise]. Lviv: Piramida, $168 \mathrm{p}$.

Kashchena, N. B. (2018). Teoretychni aspekty ekonomichnoi diialnosti pidpryiemstv torhivli [Theoretical aspects of economic activity of trade enterprises]. Bulletin of Odessa National University, vol. 7(72), pp. 115-121. Koknayeva, M. O. (2012). Osoblyvosti formuvannia metodychnoho instrumentariiu doslidzhennia finansovo-ekonomichnoi bezpeky torhovykh pidpryiemstv [Features of formation of methodical 
tools of research of financial and economic safety of the trade enterprises]. Economic Annals-XXI, no. 5-6, pp. 53-55.

Koptieva, H. M. (2020). Teoriia ta metodolohiia zabezpechennia ekonomichnoi bezpekybiznes-protsesiv torhovoho pidpryiemstva [Theory and methodology of economic security of business processes of a commercial enterprise]. Kharkiv: NUKHP, $254 \mathrm{p}$.

Kutsyk, P. O., \& Protsykevych, A. I. (2018). Stratehichni priorytety ta ochikuvani rezultaty derzhavnoho rehuliuvannia investytsiinoho protsesu na rynku IT-posluh [Strategic priorities and expected results of state regulation of the investment process in the market of IT services]. Economy and society, no. 18, pp. 140-149.

Kutsyk, P., Lupak, R., Kutsyk, V., \& Protsykevych, A. (2020). State Policy of the Investment Processes Development on the Market of IT Services: Analytical and Strategic Aspects of Implementation in Ukraine. Economic Annals-XXI, vol. 182, issue 3-4, pp. 64-76.

Kutsyk, P. O., Vasyltsiv, T. H., \& Lupak, R. L. (2016). Teoretyko-metodychni zasady ta skladovi mekhanizmy derzhavnoho rehuliuvannia rozvytku vnutrishnoi torhivli [Theoretical and methodological principles and applied mechanisms of state regulation of domestic trade]. Lviv: LTEU, $426 \mathrm{p}$.

Lupak, R., \& Kunytska, M. (2017). Conceptual Relationships between the Systems of Ensuring the Economic Security of the State and the Implementation of the State Policy of Import Substitution. Problemy Ekonomiky, no. 2, pp. 117-123.

Savchenko, I., \& Nagorna, I. (2018). The Evaluation of Methodological Aspects of the Trade Enterprises Financial Stability Analysis. Buhalterinés apskaitos teorija ir praktika, no. 17-18, pp. 85-96.

State Statistics Service of Ukraine. Official web-site. URL: http://www.ukrstat.gov.ua

Staverska, T. O. (2019). Kontseptualizatsiia formuvannia ekonomichnoho mekhanizmu zabezpechennia staloho rozvytku pidpryiemstva torhivli [Conceptualization of the formation of the economic mechanism of ensuring the sustainable development of the trade enterprise]. Economic strategy and prospects for trade and services, vol. 2(30), pp. 68-77.

Vasyltsiv, T. H., Klipkova, O. I., Lupak, R. L., Mitsenko, N. G., \& Mishchuk, I. P. (2019). Monetary and financial policy of Ukraine: theoretical-empirical connections and priorities of state regulation. Financial and credit activity: problems of theory and practice, vol. 4, no. 31, pp. 320-330.

Vasyltsiv, T., Irtyshcheva, I., Lupak, R., Popadynets, N., Shyshkova, Y., Boiko, Y., \& Ishchenko, O. (2020). Economy's innovative technological competitiveness: Decomposition, methodic of analysis and priorities of public policy. Management Science Letters, vol. 10, no. 13, pp. 3173-3182.

Vozniuk, A. O. (2012). Otsinka finansovoho stanu pidpryiemstva yak neobkhidna skladova yoho ekonomichnoho rozvytku [Assessment of the financial condition of the enterprise as a necessary component of its economic development]. Innovative economy, no. 11(37), pp. 101-105. 